\title{
Localization of the Binding Regions of a Murine Monoclonal Anti-Factor VIII Antibody and a Human Anti-Factor VIII Alloantibody, Both of Which Inhibit Factor VIII Procoagulant Activity, to Amino Acid Residues Threonine ${ }^{351}$-Serine ${ }^{365}$ of the Factor VIII Heavy Chain
}

Paul A. Foster, Carol A. Fulcher, Richard A. Houghten," Sytske de Graaf Mahoney, and Theodore S. Zimmerman Division of Experimental Hemostasis, Department of Basic and Clinical Research, and *Department of Molecular Biology, Scripps Clinic and Research Foundation, La Jolla, California 92037

\begin{abstract}
We have localized the binding region of a previously described monoclonal anti-factor VIII (FVIII) inhibitory antibody (C5) to amino acid residues $\mathrm{Thr}^{351}-\mathrm{Ser}^{365}$ of the thrombin-generated 54-kD fragment of the heavy chain of FVIII. Synthetic FVIII peptides were examined for the ability to competitively inhibit the binding of C5 to FVIII in an ELISA system. The synthetic FVIII peptide $\mathrm{Thr}^{351}-\mathrm{Ser}^{365}$ blocked C5 binding to FVIII in a dose-dependent manner in this system. Two other synthetic FVIII peptides, Asn ${ }^{340}-G^{354}$ and Glu $^{342}-$ Asp $^{356}$, which partially overlapped $\mathrm{Thr}^{351}-\mathrm{Ser}^{365}$, also blocked C5 binding to FVIII. Blocking of $\mathrm{C} 5$ binding with these peptides, however, required much greater concentrations ( $>100$ times stronger) than that required for $\mathrm{Thr}^{351}-\mathrm{Ser}^{365}$. The $\mathrm{Thr}^{351}-\mathrm{Ser}^{365}$ peptide also neutralized the FVIII inhibitory activity of $\mathrm{C5}$ in plasma. A human FVIII inhibitor (anti-FVIII heavy chain alloantibody) was also partially neutralized by $\mathrm{Thr}^{351}-\mathrm{Ser}^{365}$. $\mathrm{Thr}^{351}$ $\mathrm{Ser}^{365}$ lies between a thrombin cleavage site $\left(\mathrm{Arg}^{372}\right)$ and an activated protein $\mathrm{C}$ cleavage site $\left(\mathrm{Arg}^{336}\right)$ and may be at or near a region of functional importance in the expression of FVIII procoagulant activity.
\end{abstract}

\section{Introduction}

Factor VIII (FVIII) ${ }^{1}$ circulates in plasma with von Willebrand factor as a noncovalently linked protein complex and plays an important role in the intrinsic pathway of coagulation. Activated FVIII functions as a nonenzymatic cofactor to accelerate the activation of factor $\mathrm{X}$ by factor IXa in the presence of calcium ions and phospholipid $(1,2)$. The production of a FVIII molecule that lacks procoagulant activity, or the total lack of production of FVIII, results in hemophilia A, a Xlinked recessive bleeding disorder with a frequency of approximately 1 per 10,000 in the general population (3).

The mature FVIII molecule is a single chain protein of 2,332 amino acid residues with a calculated molecular mass of 264,763 daltons (4). FVIII purified from plasma by means of immunoaffinity chromatography consists of heterodimers of

Received for publication 23 November 1987 and in revised form 8 February 1988.

1. Abbreviations used in this paper: APTT, activated partial thromboplastin time; FVIII, factor VIII.

J. Clin. Invest.

(C) The American Society for Clinical Investigation, Inc. 0021-9738/88/07/0123/06 \$2.00

Volume 82, July 1988 , 123-128 an $80-\mathrm{kD}^{2}$ light chain in association with a heavy chain-containing species of $92-210 \mathrm{kD}(5-10)$. The two chains are presumed to be associated via a calcium linkage $(7,9-12)$.

Thrombin digestion of the $80-\mathrm{kD}$ light chain results in cleavage at $\mathrm{Arg}^{1689}$ to form a carboxyl-terminal 72-kD peptide $(4,6-8,13)$. Thrombin digestion of the $92-210-\mathrm{kD}$ polypeptides results in cleavage at $\mathrm{Arg}^{740}$ with formation of the $92-\mathrm{kD}$ amino-terminal heavy chain (14) and subsequently cleavage at $\mathrm{Arg}^{372}$ with formation of a 54-kD amino-terminal subunit and a 44-kD carboxyl-terminal subunit $(4,6-8,13)$. Further thrombin digestion cleaves the $54-\mathrm{kD}$ peptide into a 30 - and a 20-kD peptide (4).

Inactivation of FVIII by activated protein $C$ has been demonstrated to occur by cleavage of the $92-\mathrm{kD}$ peptide, or its 54-kD thrombin cleavage fragment, at the proposed cleavage site $\operatorname{Arg}^{336}$, with generation of a 45-kD fragment $(7,15)$. Factor $\mathrm{Xa}$ inactivates FVIII by the same cleavage as activated protein $\mathrm{C}$ as well as by cleavage of the $72-\mathrm{kD}$ peptide at $\mathrm{Arg}^{1721}$ with generation of a $67-\mathrm{kD}$ peptide (7).

The production of recombinant cDNA FVIII molecules with site-specific deletions and substitutions has helped identify critical thrombin cleavage sites necessary for activation of FVIII. These studies have shown that modification or deletion of the thrombin cleavage sites at $\mathrm{Arg}^{372}$ or $\mathrm{Arg}^{1689}$ result in loss of, or marked reduction of, FVIII cofactor activity (16-18). It has also been demonstrated that alteration in the proposed activated protein $\mathrm{C}$ and factor $\mathrm{Xa}$ cleavage site at $\mathrm{Arg}^{336}$ results in a FVIII molecule with higher specific activity than normal, possibly due to resistance to proteolytic inactivation (16). The above data are consistent with the observation of Fay that the $72 / 54$ heterodimer is an active form of FVIII (19).

FVIII inhibitors are human antibodies that neutralize the procoagulant activity of FVIII. Inhibitors arise as alloantibodies in $\sim 8-16 \%$ of individuals with hemophilia $A(20)$ and can arise spontaneously as autoantibodies in nonhemophiliacs. Monoclonal and polyclonal anti-FVIII antibodies that inhibit FVIII procoagulant activity have also been produced by immunization of animals with highly purified human FVIII. Since no entirely satisfactory method of treatment of FVIII inhibitors exists, the elucidation of the mechanisms of inhibition of FVIII procoagulant activity of such antibodies is of great clinical importance. Inhibitory anti-FVIII antibodies have been shown to react with several different areas of the

2. The specific peptides produced by proteolytic processing of human FVIII have been described by several investigators with slight variations in reported molecular mass $(4,6-8,10$; see also references 15,36 , and 37). For the purpose of discussion in this paper, the molecular mass of FVIII peptides produced by thrombin and activated protein $\mathrm{C}$ proteolysis will be as reported by Fulcher et al. $(6,15)$. 
FVIII molecule, indicating the heterogeneous nature of the epitopes of these antibodies $(6,8,21-25)$.

In the studies reported here, synthetic FVIII peptides have been used to localize the binding regions of a FVIII-inhibiting monoclonal antibody (C5), and a human FVIII inhibitor alloantibody to the same 15-amino acid segment of the heavy chain of FVIII. This region is located between two important thrombin $\left(\mathrm{Arg}^{372}\right)$ and activated protein $\mathrm{C}\left(\mathrm{Arg}^{336}\right)$ proteolytic cleavage sites and is likely to be at, or near, one or more sites of functional importance to the FVIII molecule.

\section{Methods}

Purification of FVIII. The purification of FVIII from commercial factor VIII concentrates (Armour Pharmaceutical Co., Kankakee, IL) by immunoadsorbent chromatography has previously been described $(5$, $6,13)$. FVIII preparations prepared by this method had specific activities of 2,900-3,800 U/mg.

Monoclonal antibodies. Murine monoclonal anti-human FVIII antibodies were produced, purified, and characterized as described (6).

Coagulation assays. Inhibition of FVIII activity by FVIII antibodies was measured in Bethesda units by a modification of the method of Kasper et al. (26) as previously described (6). FVIII procoagulant activity was determined by an activated partial thromboplastin time (APTT) assay as previously described (5) using an MLA Electra 700 automatic coagulation timer (Medical Laboratory Automation, Inc., Mount Vernon, NY).

Blocking of C5 FVIII inhibitory activity by FVIII synthetic peptides. $\mathrm{C5}(10 \mu \mathrm{g})$ was incubated for $16-18 \mathrm{~h}$ at room temperature with synthetic FVIII peptide in a final concentration of 0-5 mM. After incubation, the C5-synthetic FVIII peptide mixture was added to an equal volume $(50 \mu \mathrm{l})$ of pooled normal plasma, and a standard Bethesda assay $\left(2-\mathrm{h}\right.$ preincubation, $\left.37^{\circ} \mathrm{C}\right)$ was performed $(26)$. C5 at a concentration of $10 \mu \mathrm{g} / 50 \mu \mathrm{l}$ was equivalent to an inhibitor plasma of 2.3 Bethesda units. Control incubations included substituting barbital-buffered saline ( $0.025 \mathrm{M}$ barbital buffer, $0.125 \mathrm{M} \mathrm{NaCl}, \mathrm{pH} 7.56$ ) for the FVIII peptide or for C5. Each assay was performed in duplicate and the results were averaged. Results of the assay are reported as the number of seconds the APTT is prolonged over that of control. The control assay was defined as the APTT of normal pooled plasma preincubated for $2 \mathrm{~h}$ at $37^{\circ} \mathrm{C}$ with a equal volume of barbital-buffered saline containing the concentration of synthetic FVIII peptide being tested.

Blocking of human FVIII inhibitor alloantibody by synthetic FVIII peptides. Synthetic FVIII peptide was incubated at a final concentration of 0-5 mM with FVIII inhibitor plasma diluted 1:9 with barbitalbuffered saline and assayed as described above. The FVIII inhibitory activity of the inhibitor plasma diluted 1:9 was equivalent to an undiluted inhibitor plasma of 4.7 Bethesda units. Further studies were done with partially purified inhibitor prepared as follows: $3.9 \mathrm{ml}$ of FVIII inhibitor plasma was centrifuged and treated with $10 \mu \mathrm{M} p$-amidinophenylmethanesulfonyl fluoride (Chemicon, El Segundo, CA). The plasma was applied to a $1.0 \times 11-\mathrm{cm}$ protein $A$ column. After washing the column with phosphate-buffered saline $\left(0.02 \mathrm{M} \mathrm{PO}_{4}, 0.15 \mathrm{M} \mathrm{NaCl}\right.$, $\mathrm{pH} 7.2$ ) the IgG was eluted with $0.58 \% \mathrm{vol} / \mathrm{vol}$ acetic acid in $0.9 \%$ $\mathrm{wt} / \mathrm{vol} \mathrm{NaCl}$. The eluate was dialyzed and concentrated by ultrafiltration into phosphate-buffered saline and then dialyzed into barbitalbuffered saline. Approximately $43 \%$ of the inhibitory activity in Bethesda units and $35 \mathrm{mg}$ of IgG were recovered. A $1.0-\mathrm{ml}$ immunoadsorbent was prepared by coupling the $\mathrm{Thr}^{351}-\mathrm{Ser}^{365}$ peptide to cyanogen bromide-activated Sepharose (Pharmacia Fine Chemicals, Piscataway, NJ) according to manufacturer's instructions at a density of $2 \mu \mathrm{mol} / \mathrm{ml}$ of swollen gel. The purified IgG $(6.7 \mathrm{mg})$ was mixed batchwise with the gel overnight $(16-18 \mathrm{~h})$ at room temperature. After washing with barbital-buffered saline, the bound IgG was eluted with $0.05 \mathrm{M}$ diethylamine in barbital-buffered saline ( $\mathrm{pH} 11)$. The eluate was immediately neutralized with monobasic sodium phosphate, made $0.01 \%$ in bovine serum albumin, and concentrated and dialyzed into barbital-buffered saline by centrifugal ultrafiltration. The enriched FVIII inhibitor preparation was diluted to produce a preparation of approximately equivalent FVIII inhibitory activity as that of the inhibitor plasma in a 1:9 dilution. The enriched FVIII inhibitor was then preincubated with synthetic FVIII peptide and assayed as described above.

FVIII ELISA. In this system, purified human FVIII was diluted to $\sim 3 \mathrm{U} / \mathrm{ml}$ in $20 \mathrm{mM}$ Tris- $\mathrm{HCl}, 0.02 \% \mathrm{NaN}_{3}, \mathrm{pH} 9.6$, and $100 \mu \mathrm{l}$ added to each $1.0 \times 0.6-\mathrm{cm}$ well of a multiwell tissue culture plate (Linbro, Flow Laboratories Inc., McLean, VA) and incubated at room temperature for $2 \mathrm{~h}$. The plates were then stored in this solution at $4^{\circ} \mathrm{C}$ until use. Prior to use, the solution was removed and the wells were blocked with $200 \mu \mathrm{l}$ of $20 \mathrm{mM}$ Tris- $\mathrm{HCl}, 0.02 \% \mathrm{NaN}_{3}, 1 \%$ bovine serum albumin for $1 \mathrm{~h}$ at room temperature. After blocking, the solution was removed and the wells were washed three times with $250 \mu$ l of a buffer containing $0.14 \mathrm{M} \mathrm{NaCl}, 0.0015 \mathrm{M} \mathrm{KH}_{2} \mathrm{PO}_{4}, 0.0084 \mathrm{M} \mathrm{Na}_{2} \mathrm{HPO}_{4}$, $0.05 \%$ Nonidet P-40 (washing buffer). Alternatively, purified FVIII was diluted in $0.01 \mathrm{M} \mathrm{NaHCO}_{3}$ and $100 \mu \mathrm{l}$ was added to each well. The plates were then desiccated at room temperature, and stored at $4^{\circ} \mathrm{C}$ until use. Prior to use, the wells were blocked and washed as described above. $100 \mu \mathrm{l}$ of sample solution containing monoclonal antibody C5 and synthetic FVIII peptide was then added to each well. C5 at a final concentration of $0.4-1 \mu \mathrm{g} / \mathrm{ml}$, and FVIII peptide at a final concentration of $1 \mu \mathrm{M}$ to $1 \mathrm{mM}$ in washing buffer with $1 \%$ bovine serum albumin, were preincubated for $2 \mathrm{~h}$ at $37^{\circ} \mathrm{C}$ or overnight $\left(16-18 \mathrm{~h}\right.$ ) at $4^{\circ} \mathrm{C}$ before addition to the wells. After a 1-h incubation at room temperature, the sample solution was removed and the wells washed three times with $250 \mu \mathrm{l}$ of washing buffer. $100 \mu \mathrm{l}$ of peroxidase goat antimouse IgG $(\mathrm{H}+\mathrm{L})$ (Zymed Laboratories, Inc., San Francisco, CA) diluted $1: 2,000$ with washing buffer with $1 \%$ bovine serum albumin was added to each well and incubated for $1 \mathrm{~h}$ at room temperature. The solution was then removed and the wells washed four times with $250 \mu \mathrm{l}$ of washing buffer. $100 \mu \mathrm{l}$ of $O$-phenylenediamine substrate (Zymed Laboratories, Inc.) dissolved in $0.024 \mathrm{M}$ citric acid, $0.051 \mathrm{M}$ $\mathrm{Na}_{2} \mathrm{HPO}_{4}$, and $0.03 \%$ hydrogen peroxide was added to each well and incubated at room temperature for 5-10 min before the reaction was quenched with $100 \mu \mathrm{l}$ of $2 \mathrm{M} \mathrm{H}_{2} \mathrm{SO}_{4}$. The color change in each well was read on an MR 600 microplate reader (Dynatech Instruments, Inc., Torrance, CA). Results of the assay are reported as the percentage of inhibition of $\mathrm{C} 5$ binding. Percent inhibition of $\mathrm{C} 5$ binding is defined as $100 \%-100 \times$ (the absorbance reading of $\mathrm{C} 5$ binding in the presence of synthetic FVIII peptide divided by the absorbance of $\mathrm{C} 5$ binding in the absence of synthetic FVIII peptide). Each sample was assayed in duplicate or triplicate and the results were averaged.

Protein concentrations. Protein concentrations were determined by the method of Bradford (27) or the method of Lowry et al. as modified by Peterson (28).

Peptide synthesis. Synthetic FVIII peptides were produced as previously described by Houghten (29).

\section{Results}

The binding site of $\mathrm{C} 5$ has been previously reported to be localized to the $92-\mathrm{kD}$ heavy chain subunit of FVIII by immunoblotting techniques. The binding site was not thrombin sensitive as shown by the binding of $\mathrm{C} 5$ to the $54-\mathrm{kD}$ thrombin cleavage product of FVIII heavy chain (6). Fig. 1 schematically depicts the mature FVIII protein and denotes the thrombin, factor $\mathrm{Xa}$, and activated protein $\mathrm{C}$ cleavage sites and the resulting fragments (7).

In order to further localize the C5-binding region, synthetic FVIII peptides, corresponding to amino acid sequences from the carboxyl-terminal region of the 54-kD thrombin cleavage product of FVIII heavy chain, were tested for their ability to 


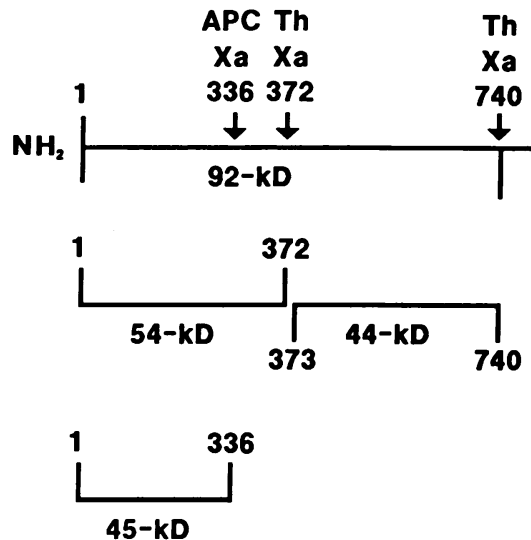

45-kD
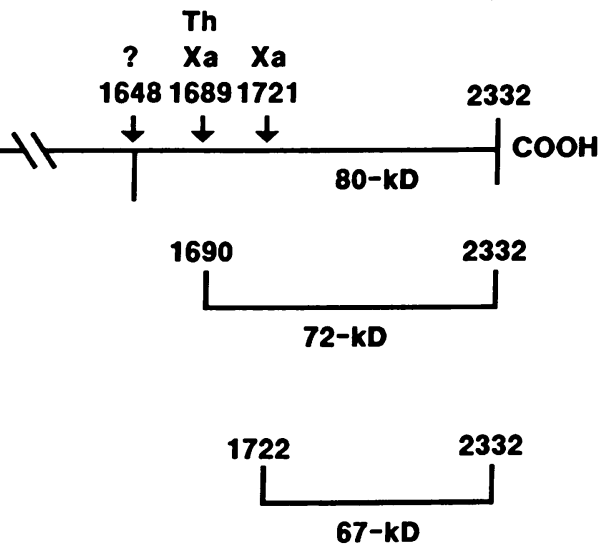

Figure 1. Line diagram of the FVIII molecule and its proteolytic fragments. The top line depicts the mature FVIII molecule. The arrows represent the known or proposed thrombin $(T h)$, factor $\mathrm{Xa}(X a)$, and activated protein $\mathrm{C}(A P C)$ cleavage sites. The numbers above the arrows indicate the amino acid residue number of the amino terminus of each cleavage site. The subunits produced by these cleavages are shown below the mature molecule with the first and last amino acid residue number noted. The molecular mass of each subunit is shown below its line diagram $(4,7,11)$. block the binding of C5 to FVIII adsorbed to the surface of microtiter wells in an ELISA system. Synthetic peptides based on the amino acid sequence of FVIII light chain were used as control peptides. Fig. 2 depicts the amino acid sequence of amino acid residues 330-376 of the heavy chain of FVIII, the activated protein $\mathrm{C}$ cleavage site at $\mathrm{Arg}^{336}$, and the thrombin cleavage site at $\operatorname{Arg}^{372}$ (7). The amino acid sequence of the synthetic peptides used in these studies is also depicted in this figure.

In the ELISA system, the synthetic FVIII peptide $\mathrm{Thr}^{351}$ $\mathrm{Ser}^{365}$ demonstrated dose-dependent inhibition of C5 binding to FVIII with $\sim 50 \%$ of maximal inhibitory activity at a concentration of $0.75 \mu \mathrm{M}$ and near total inhibition at a concentration of $100 \mu \mathrm{M}$ (Fig. 3). Two other peptides, Asn ${ }^{340}-\mathrm{Glu}^{354}$ and $\mathrm{Glu}^{342}-\mathrm{Asp}^{356}$, demonstrated partial inhibition of $\mathrm{C5}$ binding but at an $\sim 100$-fold greater concentration than that required for $\mathrm{Thr}^{351}-\mathrm{Ser}^{365}$ (Fig. 3). The amino acid sequences of these three peptides partially overlap and have in common the amino acid residues 351-354 (Fig. 2). Since all three peptides have some reactivity with $\mathrm{C} 5$, then the $\mathrm{C} 5$-binding region must involve one or more amino acid residues in the common sequence. However, given the marked difference in concentration requirements to demonstrate reactivity, the C5-binding region must also involve additional amino acid residues between residue numbers 357 and 365 , which are not contained in the overlap. Light chain control peptides $\mathrm{Arg}^{1645}-\mathrm{Gln}^{1659}$ and $\mathrm{Val}^{1670}-\mathrm{Glu}^{1684}$ failed to demonstrate any inhibition of C5 binding at concentrations up to $1 \mathrm{mM}$ (Fig. 3).

Since C5 demonstrated inhibition of FVIII procoagulant activity in plasma, the individual synthetic FVIII peptides were tested for the ability to neutralize this effect of C5. Fig. 4 demonstrates that the $\mathrm{Thr}^{351}-\mathrm{Ser}^{365}$ peptide was able to neu- tralize C5-induced prolongation of the APTT in a dose-dependent manner with near total neutralization at a final concentration of $3 \mathrm{mM}$. Partially overlapping peptides $\mathrm{Ass}^{340}$ $\mathrm{Glu}^{354}, \mathrm{Val}^{357}-\mathrm{Ile}^{371}$, and $\mathrm{Glu}^{342}-\mathrm{Asp}^{356}$ had no effect on the prolongation of the APTT by $\mathrm{C} 5$ at concentrations up to 4-5 mM (Fig. 4). Likewise, light chain control peptides Glu ${ }^{1660}$ Lys $^{1674}$ and Arg ${ }^{1781}$-Asp ${ }^{1795}$ had no effect (data not shown). The neutralization of the FVIII inhibitory activity of C5 by $\mathrm{Thr}^{351}-\mathrm{Ser}^{365}$ demonstrated in Fig. 4 is not the result of any artifactual shortening of the APTT assay caused independently by the peptide. The synthetic FVIII peptide had a minimal effect on the APTT assay. With a control APTT value of $66.3 \mathrm{~s}$ (normal plasma 1:1 with barbital-buffered saline), the addition of FVIII peptide to a final concentration of 3-5 mM resulted in the following APTT values; $66.2 \mathrm{~s}$ for $\mathrm{Thr}^{351}-\mathrm{Ser}^{365}, 65.8 \mathrm{~s}$ for $\mathrm{Val}^{357}-\mathrm{Ile}^{371}, 68.6 \mathrm{~s}$ for $\mathrm{Asn}^{340}-\mathrm{Glu}^{354}$ and $65.9 \mathrm{~s}$ for $\mathrm{Glu}^{342}$-Asp ${ }^{356}$.

The ability of the $\mathrm{Thr}^{351}-\mathrm{Ser}^{365}$ peptide to neutralize a human FVIII inhibitor was then assessed. An oligoclonal inhibitor with known reactivity to both the 54-kD thrombin cleavage product, which contains the $\mathrm{Thr}^{351}-\mathrm{Ser}^{365}$ sequence, and the 44-kD thrombin cleavage product of the 92-kD FVIII heavy chain, was used (30, patient D). In a standard Bethesda type assay (26), this FVIII inhibitor produced a 26 -s prolongation in the APTT assay. Preincubation of the FVIII inhibitor plasma with the $\mathrm{Thr}^{351}-\mathrm{Ser}^{365}$ peptide at a final concentration of $2.5 \mathrm{mM}$ resulted in a 12-s reduction of the prolongation of the APTT produced by the FVIII inhibitor plasma. Doubling the concentration of the peptide to $5 \mathrm{mM}$ did not result in any further reduction of the APTT prolongation. Preincubation with $\mathrm{Asn}^{340}-\mathrm{Glu}^{354}$ or $\mathrm{Glu}^{342}-\mathrm{Asp}^{356}$ peptides at the same final concentrations resulted in no significant reduction in the pro-

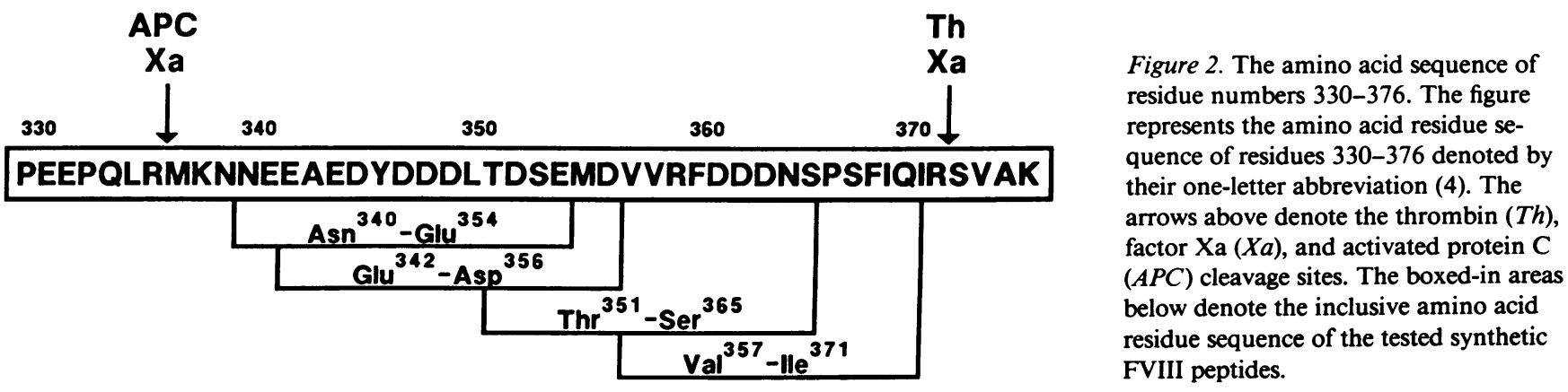




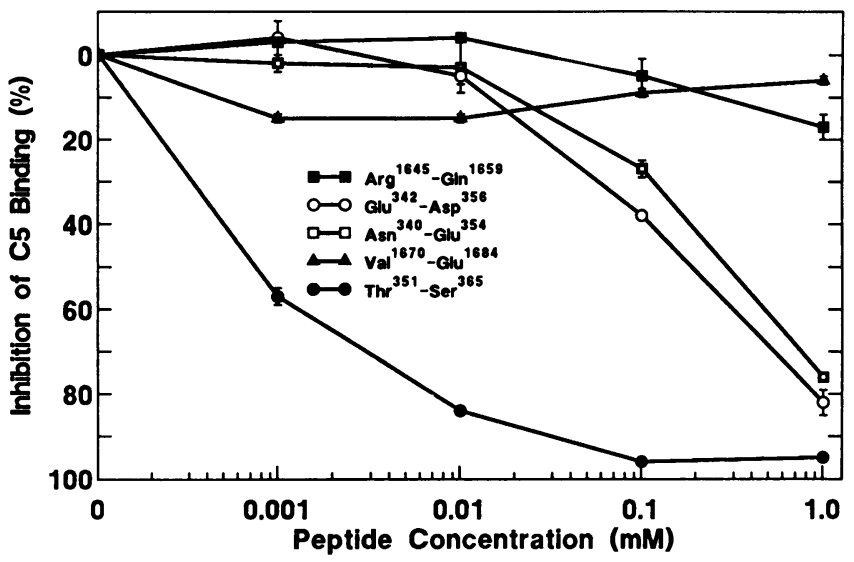

Figure 3. Inhibition of C5 binding to FVIII by synthetic FVIII peptides. C5 $(0.7 \mu \mathrm{g} / \mathrm{ml}, 4.5 \mathrm{nM})$ was preincubated with synthetic FVIII peptides $(0-1 \mathrm{mM})$ before the binding of $\mathrm{C} 5$ was determined in an ELISA assay. The data are plotted as percent inhibition of $\mathrm{C} 5$ binding produced by preincubation of $\mathrm{C} 5$ with the indicated synthetic peptide. Error bars represent the standard deviation of the mean of two to three determinations. Standard deviations of $1 \%$ or less are not indicated by error bars.

longation of the APTT. Preincubation of a human FVIII inhibitor, which reacts only with the thrombin-generated 72-kD FVIII light chain fragment with the $\mathrm{Thr}^{351}-\mathrm{Ser}^{365}$ peptide, also resulted in no significant reduction of the prolongation of the APTT.

This FVIII inhibitor was also examined after partial purification by protein A chromatography and immunoaffinity chromatography with $\mathrm{Thr}^{351}-\mathrm{Ser}^{365}$ peptide coupled to Sepharose. Fig. 5 demonstrates a dose-dependent neutralization of the FVIII inhibitory activity of the human FVIII inhibitor by the $\mathrm{Thr}^{351}-\mathrm{Ser}^{365}$ peptide. The peptide Glu ${ }^{1660}-\mathrm{Lys}^{1674}$, which was used as a light chain control peptide, demonstrated no neutralization of the human FVIII inhibitor under identical conditions.

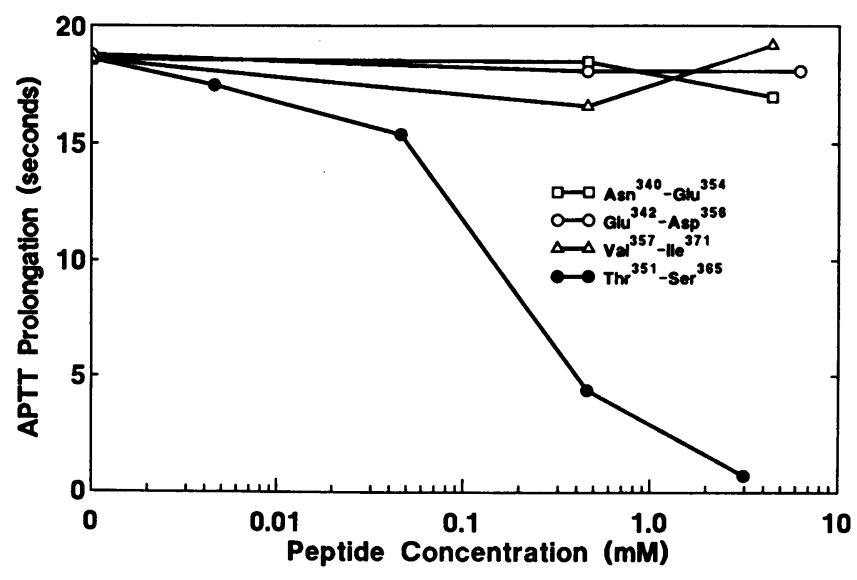

Figure 4. Neutralization of C5 FVIII inhibitory activity by synthetic FVIII peptide $\mathrm{Thr}^{351}-\mathrm{Ser}^{365}$. C5 $(10 \mu \mathrm{g})$ was preincubated with synthetic FVIII peptide (0-5 $\mathrm{mM}$ ) before testing its FVIII inhibitory activity in a standard Bethesda assay. Data are plotted as the number of seconds the APTT is prolonged over a control assay containing the synthetic FVIII peptide at the concentration tested, but no C5.

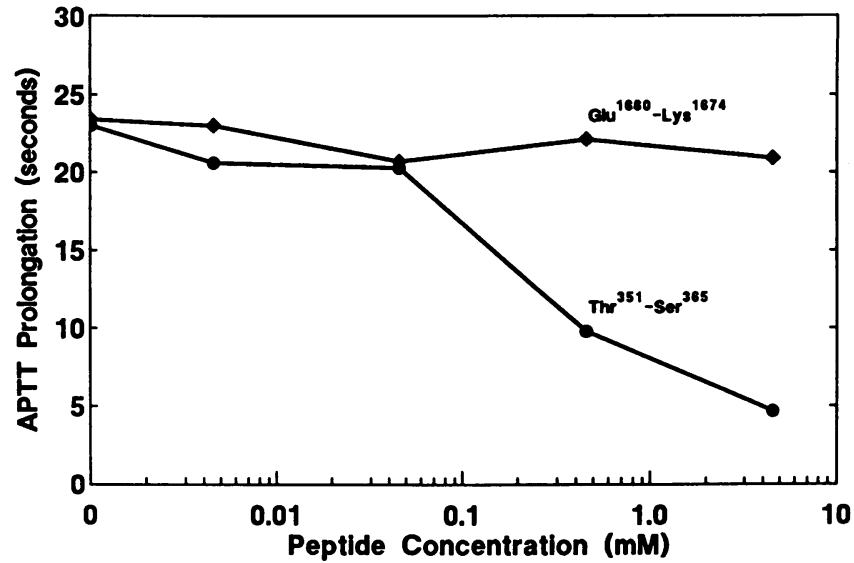

Figure 5. Neutralization of a human FVIII inhibitor alloantibody by synthetic FVIII peptide $\mathrm{Thr}^{351}-\mathrm{Ser}^{365}$. A human FVIII inhibitor alloantibody partially purified from plasma was preincubated with synthetic FVIII peptides before testing in a standard Bethesda assay. Data are plotted as the number of seconds the APTT is prolonged over a control assay containing no synthetic FVIII peptide. Synthetic FVIII peptide alone had no effect on the APTT.

\section{Discussion}

The results presented here clearly demonstrate that the binding region of the FVIII-inhibiting monoclonal antibody C5 and a human FVIII inhibitor alloantibody resides between amino acid residues $\mathrm{Thr}^{351}-\mathrm{Ser}^{365}$. The localization of the $\mathrm{C5}$ binding area to this same general region of FVIII has also been demonstrated by entirely different methods. Recombinant cDNA techniques have been used to generate a series of clones expressing FVIII fragments. These clones were immunologically screened with $\mathrm{C5}$ and the overlapping DNA sequences determined. The $\mathrm{C5}$-binding region was restricted to a region of FVIII between amino acid residues 338-362 by this method (31). In addition, the immunoblot reactivity of C5 with a bacterially produced FVIII fragment containing amino acid residues 326-740 also localized the epitope to residues 326-372 (unpublished observations). The synthetic FVIII peptide method not only allows further restriction of the binding site, but also assures specificity by demonstrating blocking of the FVIII inhibitory activity of C5 in fluid phase.

Localization of the C5-binding region to amino acid residues $\mathrm{Thr}^{351}-\mathrm{Ser}^{365}$, which lies between two critical cleavage sites in the FVIII heavy chain, suggests that it is at, or near, structures important to the modulation of FVIII procoagulant activity. As proposed by Eaton et al. (7), thrombin cleavage of the $92-\mathrm{kD}$ heavy chain at $\mathrm{Arg}^{372}$ produces $54-$ and $44-\mathrm{kD}$ subunit peptides and results in FVIII procoagulant activity (Fig. 1). Cleavage of the $54-\mathrm{kD}$ peptide at $\mathrm{Arg}^{336}$ by activated protein $\mathrm{C}$ or factor $\mathrm{Xa}$ results in production of a $45-\mathrm{kD}$ cleavage peptide and loss of FVIII procoagulant activity (7) (Fig. 1). They suggested that the region between these two cleavage sites may be functionally important in regulating FVIII procoagulant activity. The description of a binding epitope of a FVIII inhibitory antibody to this region supports this supposition. It is further supported by the finding that this peptide segment also partially neutralizes a human FVIII inhibitor alloantibody. 
The FVIII inhibitory activity of the human alloantibody tested was only partially neutralized by preincubation with the $\mathrm{Thr}^{351}-\mathrm{Ser}^{365}$ peptide at concentrations up to $5 \mathrm{mM}$. This is consistent with the observation that the antibody is oligoclonal in nature and has reactivity with both the 54- and 44-kD thrombin generated fragments of FVIII heavy chain (30). Partial purification of the FVIII inhibitor by protein A chromatography followed by immunoaffinity chromatography with the $\mathrm{Thr}^{351}-\mathrm{Ser}^{365}$ peptide coupled to Sepharose appears to have resulted in the recovery of a population of FVIII inhibitor which was more completely neutralized by the $\mathrm{Thr}^{351}-\mathrm{Ser}^{365}$ peptide. Incubation of the inhibitor plasma with $2.5 \mathrm{mM}$ $\mathrm{Thr}^{351}-\mathrm{Ser}^{365}$ resulted in a $46 \%$ reduction in the APTT prolongation produced by the inhibitor plasma. No further reduction was noted with incubation at a concentration of $5 \mathrm{mM}$ peptide. Incubation of a preparation of partially purified inhibitor (containing the same Bethesda unit activity as the inhibitor plasma) with $5 \mathrm{mM}$ peptide resulted, however, in a $80 \%$ reduction of the APTT prolongation. Some of the FVIII inhibitory activity of this patient's plasma may result from alloantibodies reactive with the 44-kD FVIII heavy chain fragment. FVIII inhibitory alloantibodies with reactivity only to the 44$\mathrm{kDa}$ fragment have been described (30).

The region that contains the C5-binding area, is an unusually acidic region of the protein. This acidic region (amino acid residues 331-372) contains 15 aspartic and glutamic acid residues with only four lysine or arginine residues out of 42 amino acids $(4,7,11)$ (Fig. 2). The region also functions as a spacer region between the first (amino acid residues 1-328) and second (amino acid residues 380-711) A domains (11). An analogous acidic region occurs in the light chain (amino acid residues 1649-1689) which also contains 15 aspartic and glutamic acid residues and only four lysine or arginine residues out of 41 amino acids $(4,7,11)$. This latter acidic region also preceeds a critical thrombin cleavage site at $\mathrm{Arg}^{1689}$ necessary for activation of FVIII $(4,16)$. These two acidic regions also contain some amino acid residue sequence homology $(32,33)$. The control peptides used in this study contained amino acid sequences from the acidic region of the light chain. It is therefore unlikely that the results obtained here were simply a result of the acidic nature of the peptides. It is of interest that the binding region of a FVIII-inhibiting anti-FVIII peptide antibody has been localized to a seven-amino acid segment of the acidic region of the light chain (23).

The actual mechanism of the inhibition of FVIII procoagulant activity by $\mathrm{C} 5$ or the alloantibody inhibitor is not known. The binding of these antibodies may inhibit FVIII activation by interfering with the thrombin cleavage at $\mathrm{Arg}^{372}$ (Fig. 1). This mechanism of inhibition has been postulated as the cause of FVIII inactivation by a FVIII inhibitor (34). Binding of these antibodies could sterically block the thrombin cleavage site, or render it inaccessible through the induction of conformational changes in the FVIII molecule. It is also possible that their binding has no effect on thrombin cleavage, but prevents the effective interaction or binding of FVIII with other constituents of the coagulation mechanism such as factor IXa, factor $\mathrm{X}$, calcium ions, or phospholipid.

There is evidence that the acidic regions of FVIII may be involved in protein-protein interactions. A monoclonal antiFVIII antibody, whose binding region is contained within the acidic region of the light chain of FVIII, has been reported to block the binding of FVIII to von Willebrand factor (35).
The mechanisms of action of FVIII inhibitors are most likely heterogeneous. Other inhibitory antibodies have been localized to amino acid residues 1663-1669 (amino-terminal region of the light chain) (23), to the carboxyl-terminal 19-kD portion of the light chain (22), to the amino-terminal 19.4-kD portion of the 44-kD subunit of the heavy chain (22), and to amino acid residues 701-766 (carboxyl-terminal portion of the 44-kD subunit) (31). Such a wide distribution of epitopes for FVIII inhibitory antibodies implies heterogeneous mechanisms of inactivation.

The techniques presented in this study may be helpful in localization of the binding regions of other FVIII inhibitors. Elucidation of the binding regions and mechanisms of action of FVIII inhibitors should help provide better understanding of the structure-function relationships of the FVIII molecule, and hopefully lead to new therapeutic insights into the treatment of patients with FVIII inhibitors.

\section{Acknowledgments}

This work was supported in part by grants HL-35090, HL-15491, HL-31950, and AM-07022 from the National Institutes of Health.

\section{References}

1. Hultin, M. B., and Y. Nemerson. 1978. Activation of factor Xa by factors IXa and VIII: a specific assay for factor IXa in the presence of thrombin-activated factor VIII. Blood. 52:928-940.

2. van Dieijen, G., G. Tans, J. Rosing, and H. C. Hemker. 1981. The role of phospholipid and factor VIIIa in the activation of bovine factor X. J. Biol. Chem. 256:3433-3442.

3. Levine, P. H. 1987. Clinical manifestations and therapy of hemophilias A and B. In Hemostasis and Thrombosis. 2nd edition. R. W. Coleman, J. Hirsh, V. J. Marder, and E. W. Salzman, editors. J. P. Lippincott Co., Philadelphia. 97-111.

4. Vehar, G. A., B. Keyt, D. Eaton, H. Rodriguez, D. P. O'Brien, F. Rotblat, H. Oppermann, R. Keck, W. I. Wood, R. N. Harkins, E. G. D. Tuddenham, R. M. Lawn, and D. J. Capon. 1984. Structure of human factor VIII. Nature (Lond.). 312:337-342.

5. Fulcher, C. A., and T. S. Zimmerman. 1982. Characterization of the human factor VIII procoagulant protein with a heterologous precipitating antibody. Proc. Natl. Acad. Sci. USA. 79:1648-1652.

6. Fulcher, C. A., J. R. Roberts, L. Z. Holland, and T. S. Zimmerman. 1985. Human factor VIII procoagulant protein. Monoclonal antibodies define precursor-product relationships and functional epitopes. J. Clin. Invest. 76:117-124.

7. Eaton, D., H. Rodriguez, and G. A. Vehar. 1986. Proteolytic processing of human factor VIII. Correlation of specific cleavages by thrombin, factor $\mathrm{Xa}$, and activated protein $\mathrm{C}$ with activation and inactivation of factor VIII coagulant activity. Biochemistry. 25:505-512.

8. Rotblat, F., D. P. O'Brien, F. J. O'Brien, A. H. Goodall, and E. G. D. Tuddenham. 1985. Purification of human factor VIII:C and its characterization by western blotting using monoclonal antibodies. Biochemistry. 24:4294-4300.

9. Fass, D. N., G. J. Knutson, and J. A. Katzmann. 1982. Monoclonal antibodies to porcine factor VIII coagulant and their use in the isolation of active coagulant protein. Blood. 59:594-600.

10. Fay, P. J., M. T. Anderson, S. I. Chavin, and V. J. Marder. 1986. The size of human factor VIII heterodimers and the effects produced by thrombin. Biochim. Biophys. Acta. 871:268-278.

11. Eaton, D. L., and G. A. Vehar. 1986. Factor VIII structure and proteolytic processing. Prog. Hemostasis Thromb. 8:47-70.

12. Eaton, D. L., P. E. Hass, L. Riddle, J. Mather, M. Wiebe, T. Gregory, and G. A. Vehar. 1987. Characterization of recombinant human factor VIII. J. Biol. Chem. 262:3285-3290.

13. Fulcher, C. A., J. R. Roberts, and T. S. Zimmerman. 1983. 
Thrombin proteolysis of purified factor VIII procoagulant protein: correlation of activation with generation of a specific polypeptide. Blood. 61:807-811.

14. Toole, J. J., J. L. Knopf, J. M. Wozney, L. A. Sultzman, J. L. Buecker, D. D. Pittman, R. J. Kaufman, E. Brown, C. Shoemaker, E. C. Orr, G. W. Amphlett, W. B. Foster, M. L. Coe, G. J. Knutson, D. N. Fass, and R. M. Hewick. 1984. Molecular cloning of a cDNA encoding human antihaemophilic factor. Nature (Lond.). 312:342347.

15. Fulcher, C. A., J. E. Gardiner, J. H. Griffin, and T. S. Zimmerman. 1984. Proteolytic inactivation of human factor VIII procoagulant protein by activated human protein $\mathrm{C}$ and its analogy with factor $\mathrm{V}$. Blood. 63:486-489.

16. Pittman, D. D., L. C. Wasley, B. L. Murray, J. H. Wang, and R. J. Kaufman. 1987. Analysis of structural requirements for factor VIII function using site-directed mutagenesis. Thromb. Haemostasis. 58:344. (Abstr.)

17. Rosenberg, S., K. Hartog, O. Nordfang, M. Ezban, and R. L. Burke. 1987. The functional domains of coagulation factor VIII. Thromb. Haemostasis. 58:222. (Abstr.)

18. Toole, J. J., D. Pittman, P. Murtha, L. C. Wasley, J. Wang, G. Amphlett, R. Hewick, W. B. Foster, R. Kamen, and R. J. Kaufman. 1986. Exploration of structure-function relationships in human factor VIII by site-directed mutagenesis. Cold Spring Harbor Symp. Quant. Biol. 51:543-549.

19. Fay, P. J. 1987. Thrombin-activated factor VIlla is composed of a noncovalent 73/51 kD dimer. Thromb. Haemostasis. 58:343. (Abstr.)

20. Roberts, H. R. and R. Cromartie. 1985. Overview of inhibitors to factor VIII and IX. Prog. Clin. Biol. Res. 150:73-85.

21. Fulcher, C. A., S. de Graaf Mahoney, J. R. Roberts, C. K. Kasper, and T. S. Zimmerman. 1985. Localization of human factor VIII inhibitor epitopes to two polypeptide fragments. Proc. Natl. Acad. Sci. USA. 82:7728-7732.

22. Scandella, D., and C. A. Fulcher. 1987. Human factor VIII inhibitors: further epitope localization and neutralization using bacterially produced factor VIII fragments. Blood. 70:394a. (Abstr.)

23. Shima, M., C. A. Fulcher, R. A. Houghten, and T. S. Zimmerman. 1987. Localization of the binding site for a factor VIII activity neutralizing antibody to amino acid residues 1663-1669. Blood. 70:395a. (Abstr.)

24. Nordfang, O., M. Ezban, J. M. Favaloro, H. H. M. Dahl, and J. J. Hansen. 1985. Specificity of monoclonal antibodies to factor VIII:C. Thromb. Haemostasis. 54:586-590.

25. Nordfang, O., M. Ezban, and B. Dinesen. 1985. Reactivity of factor VIII inhibitors in a micro ELISA for factor VIII: CAg and in solid phase immunoisolation of VIII:CAg. Thromb. Haemostasis. $54: 346-350$

26. Kasper, C. K., L. M. Aledort, R. B. Counts, J. R. Edson, J. Fratantoni, D. Green, J. W. Hampton, M. W. Hilgartner, J. Lazerson, P. H. Levine, C. W. McMillian, J. G. Pool, and S. S. Shapiro. 1975. A more uniform measurement of factor VIII inhibitors. Thromb. Diath. Haemorrh. 34:869-872.

27. Bradford, M. M. 1976. A rapid and sensitive method for the quantitation of microgram quantities of protein utilizing the principle of protein-dye binding. Anal. Biochem. 72:248-254.

28. Peterson, G. L. 1983. Determination of total protein. Methods Enzymol. 91:95-101.

29. Houghten, R. A. 1985. General method for the rapid solidphase synthesis of large numbers of peptides: specificity of antigenantibody interaction at the level of individual amino acids. Proc. Natl. Acad. Sci. USA. 82:5131-5135.

30. Fulcher, C. A., S. de Graaf Mahoney, and T. S. Zimmerman 1987. FVIII inhibitor IgG subclass and FVIII polypeptide specificity determined by immunoblotting. Blood. 69:1475-1480.

31. Ware, J., J. Toomey, C. Fulcher, and T. S. Zimmerman. 1987. Factor VIII:C antigenic determinants defined by recombinant DNA. Blood. 70:396a. (Abstr.)

32. Wood, W. I., D. J. Capon, C. C. Simonsen, D. L. Eaton, J. Gitschier, B. Keyt, P. H. Seeburg, D. H. Smith, P. Hollingshead, K. L. Wion, E. Delwart, E. G. D. Tuddenham, G. A. Vehar, and R. M. Lawn. 1984. Expression of active human factor VIII from recombinant DNA clones. Nature (Lond.). 312:330-337.

33. Gitschier, J., W. I. Wood, T. M. Goralka, K. L. Wion, E. Y. Chen, D. H. Eaton, G. A. Vehar, D. J. Capon, and R. M. Lawn. 1984 Characterization of the human factor VIII gene. Nature (Lond.) 312:326-330.

34. Lazarchick, J., M. A. Ashby, J. J. Lazarchick, and D. A. Sens. 1986. Mechanism of factor VIII inactivation by human antibodies. IV. Antibody binding prevents factor VIII proteolysis by thrombin. Ann. Clin. Lab. Sci. 16:497-501.

35. Foster, P. A., C. A. Fulcher, R. A. Houghten, and T. S. Zimmerman. 1988. An immunogenic region within residues $\mathrm{Val}^{1670}$ $\mathrm{Glu}^{1684}$ of the factor VIII light chain induces antibodies which inhibit binding of factor VIII to von Willebrand factor. J. Biol. Chem. 263:5230-5234.

36. Van de Pol, H., N. Bihoreau, A. Sauger, and V. Ganne. 1987. Isolation and characterization of activated factor VIII. Thromb. Haemostasis. 58:342. (Abstr.)

37. Sewerin, K., A. Lundin, E. Hellstrom, K. Larsen, and H. Sandberg. 1987. Activation and inactivation of purified human factor VIII by thrombin. Thromb. Haemostasis. 58:344. (Abstr.) 